\title{
3: 39296526-39279991
}

National Cancer Institute

\section{Source}

National Cancer Institute. 3: 39296526-39279991. NCI Thesaurus. Code C42031.

Physical location of CX3CR1_Gene 